\title{
The social profitability of business incubators: A measurement proposal ${ }^{2}$
}

\begin{abstract}
Public business incubators are services placed at the disposal of original, generally newly-created projects, to which physical accompaniment, supervision, and location are offered at prices below market value. They have as their aim to help set in motion and consolidate these firms during the stages in which they are weaker. The ultimate goal consists in favouring the generation of innovative firms, inducers of high-quality jobs, which can diversify the local business fabric, thus becoming a key tool in local development.

The present paper provides a methodology to study the economic -but above all social-impact of business incubators, based on the examination of 40 from the 42 incubators existing in the Valencian Community (a Spanish autonomous region with five million inhabitants). Data analysis allows us to state that, although business incubators are not economically profitable since they need financial aids and public investment to start operating, they do have social profitability, insofar as the activity developed by entrepreneurs permits to provide public administrations -via taxes- with returns exceeding what was invested in these incubators. It has been determined that 2.8 euros (which can be applied to a variety of social areas) are collected via taxes for each euro spent to start them up.
\end{abstract}

Keywords: business incubator, economic profitability, social profitability, entrepreneurship, public investment, local development, Spain suggestions.

'The authors would like to express their gratitude to the anonymous reviewers for all their helpful 


\section{Introduction}

An old factory located in Batavia (New York), with an area of $70,000 \mathrm{~m}^{2}$, the owner of which could not find a buyer, became the world's first business incubator ever in 1959. It welcomed small business initiatives that were given supervision and accompaniment services during their initial stages (M iddleton, Schaeffer and Jackson 2012). Ever since then, business incubators have become one of the most widely utilised tools worldwide when it comes to fostering the creation of enterprises and, consequently, local development.

According to the International Business Association, there were 1,250 incubators in the U.S. in 2012. In that same year, the last one for which global data are available, the UK Business Association gathered data about 300 incubators in the United Kingdom and estimated that 7,000 could be identified around the world. In Spain, the most recent study carried out in 2015 provided a figure of 578 incubators, almost twice as much as in 2012 (Blanco Jiménez et al. 2016).

The incubators operated in European countries are not so prone as the American ones to incorporate a proactive management towards their users so that the latter can generate large projects (Al-M ubaraki and Busler 2011; Aerts, Matthyssens and Vandenbempt 2007). Instead, they focus, to a greater extent, on the generic creation of firms, with a special emphasis on the quantity and quality of the jobs created (M CAdam and Marlow 2011; Lorentzen 2008).

The overall unemployment rate of $20.9 \%$ recorded in the last quarter of 2015 , as well as the fact that unemployment amongst people under 25 years of age reached a percentage of $48.3 \%$ in that same year, after having exceeded 50\% between 2012 and 2014 at the top of a long historical series forcing the younger Spanish population to migrate abroad ${ }^{2}$, explains why employment generation constitutes a priority problem in Spain. Faced with this situation, it became necessary to revise job promotion policies so that they could contain the outflow of highly qualified workers, with an estimated cost of 57 billion euros if that unemployment rate continued (De Marco and Sorando 2015). Over 218,000 young workers have left Spain since 2009.

For the Valencian Autonomous Region, this situation has been much worse due to the lack of a strong industrial sector which could generate a type of employment that neither tourism nor the low value-added services based on micro-SM Es were able to provide. At the end

${ }^{2}$ Eurostat:

http://ec.europa.eu/eurostat/tgm/table.do?tab=table\&init=1\&language=en\&pcode=tipslm80\&plugin=1 
of 2015 , the unemployment rate in this region amounted to $21.5 \%$ of the Spanish total, more than 700,000 people -increasing up to $46.4 \%^{3}$ amongst the population segment below the age of 25 . This delicate situation has raised great sensitivity towards the social profitability of public investments, such as the investment in business incubators, for instance. Doubts arise about whether incubators are just another expense of public administrations or, if on the contrary, they constitute a source of social profitability (Pergelova and Angulo-Ruiz 2014). Although there are studies analysing the profitability of the entrepreneurship policy in general (Lundström et al., 2014) and the results of business incubators in particular (Hackett and Dilts, 2008; Voisey et al., 2006), it is still necessary to continue measuring the results of investment in business incubators.

Thus, the purpose of the present study consists on looking for a methodology that can be used to measure the economic as well as social profitability of business incubators. With this aim in mind, an initial review of the literature dedicated to social profitability, business incubators, and to a variety of methods which represent attempts to assess the profitability of investments (public or not) in business activities served as the basis to design our proposal for the measurement of business incubator profitability. A description of the methodology applied to empirical work, which was based on the results of a survey performed both with the managers of incubators located in the Valencian Community and with the entrepreneurs received at those incubators. And with the information obtained, we will be able to put into practice our profitability measuring system. Finally, the paper will conclude with a summary of the main results as well as the most important conclusions drawn from our research.

\section{Social Profitability and Business Incubators}

\subsection{Social Profitability}

First of all, it is necessary to highlight the amplitude of the concept of social profitability. Given that the term profitability refers to the ability to produce a benefit or usefulness during a given period, while it is characterized as a social profitability, it is defined as that which is able to produce a benefit or usefulness to society. The term social profitability, applied to the business context, al ludes to any business activity resulting in a benefit or usefulness for society or certain social groups. From the moment it was accepted that the business objective went beyond the

\footnotetext{
${ }^{3}$ Data from INE (Spanish National Statistics Institute). http://www.ine.es
} 
income statement and maximized value, whether for the shareholders or stakeholders, the interpretation of results based on the criteria, such as the Return on Investment (ROI), focus was given to the creation of value associated with the investment projects and to the impact on the claims of said stakeholders.

Grinols and Mustard (2001) identified social profitability drawing from idea corresponding to the improvement that is produced in the welfare of all consumers, curiously drawing from the study of the impact of gambling casinos. Meanwhile, Stoforos, Kavcic, Erjavej and M ergod (2000), based on a study of agricultural performance, define social profitability as the difference between the value of goods produced and the resources invested, estimated on the basis of their social utility. Bigliardi, Dormio, Nosella and Petroni (2006) try to establish a method to analyse the results of scientific parks and show that economic and social assessment measures are currently used as social indicators. Mian (1997) makes an in-depth study on how to assess and manage the university technology business incubator. In addition, studies by Byus, Deis, and Ouyang (2010) and Kerr (2007) try to establish the relationship between a trait of social profitability (namely the fact of being a sustainable company) and its financial results. On the contrary, Burke and Logsdon (1996) argue that we should not seek a direct link between the benefits of social profitability and short-term benefits, but should instead identify long-term projects and processes that can create strategic benefits. It seems that this approach would fit appropriately with the perspective of business incubators, whose public origin does not focus much on the immediate or economic benefits but to generate consequences in the medium and long term.

Finally, the analysis by Nicholls et al. (2009) should also be mentioned, as it introduces more precisely the concept of 'Social Return on Investment' (SROI), identified as a variable that seeks measuring elements of the inequalities in various levels (social, environmental, economic, etc.), incorporating both costs and social benefits of activities.

\subsection{Business Incubators}

The existing bibliography makes it possible to identify the general characteristics of incubators as well as their influence on firms (Al-M ubaraki and Wong 2011; D'Agostino 2009; Setyawan and Suyudi 2014; Vanderstraeten and Matthyssens 2010), holistically defining incubators as instruments that contribute in the creation of firms and jobs, but without conceiving their social impact, beyond said aspects. 
Similarly, a number of attempts have been made to try and locate the most suitable forms of operation for incubators (M archis 2011; M iddleton, Schaeffer and Jackson 2012; Blanco Jiménez et al. 2016) through a comprehensive review of their structures and operational services.

Generally, the literature on this topic suggests that business incubators have numerous advantages because they increase the chances of creating firms and, therefore, jobs. Thanks to the availability of an ecosystem which makes their activity easier, the entrepreneurs accommodated in incubators stand better chances of survival than those other entrepreneurs who cannot access such facilities. In theory, firms are in a position to achieve success in their business venture because the space provided for them to settle down is complemented with the availability of advisory services at a price below market value. Additionally, incubators favour the economic and social development of the territories in which they are located, especially through the creation of firms related to highly knowledge-intensive productive sectors (Fernández Martínez et al. 2011; Canales García and Vergara González 2013; Más-Verdú et al. 2011). Nevertheless, incubators also have limitations and drawbacks, amongst which stand out the following: an excessive dependence on the granting of economic aids and subsidies; the development and building of incubators in specific territories according to political criteria, without taking into account the socioeconomic reality of those territories; the lack of analyses based on measuring valid indicators which, cannot only quantify their economic sustainability but, also provide information about their social profitability in terms of firms and jobs created; and the uncertainty with regard to the real capacity of incubators to increase the survival rate of post-incubated enterprises (Ferreiro Seoane and Vaquero García 2010).

Specifically for Spain, different research works have been carried out seeking to identify their typology (Marimón Viadiu and Alonso Martínez, 2006) or the impact of policies meant to favour entrepreneurship (Ortega Cachón 2012). The most recent study authored by Blanco jiménez et al. (2016) suggests a ranking of incubators according to the quality of the service that they offer to their users. As for the assessment of incubator economic profitability, it is worth highlighting the proposal made by Ferreiro Seoane (2014), who develops a set of potential variables through which an estimate of the economic return provided by a business incubator can be performed.

The number of incubators in Spain remained relatively low (53 facilities) until 2003. However, public administrations embarked upon the construction of business incubators from the two-year period comprised between 2003 and 2004 with the aim of improving 
entrepreneurial skills, partly due to the recommendations established at the Commission of the European Communities (European Commission 2004), where it was considered that business activity played an essential role in the promotion of innovation, competitiveness, and growth. The interest shown by various public institutions in implementing strategies that truly favoured firm creation led to a significant increase (624\%) in the number of business incubators, reaching a total of 384 facilities in 2014, and 578 in 2015 (Blanco Jiménez et al., 2016). The Valencian Community followed this trend too, and it ranked third amongst the Spanish Autonomous Regions with more than 40 incubators in 2014. It deserves to be highlighted that the number of business incubators in this region grew by $437.5 \%$ between 2004 and 2014 with two distinct stages regarding the setting in motion of these incubators: (a) the years preceding the crisis (the epicentre of which can be placed in 2007) when the Chambers of Commerce led this process; and (b) a subsequent period in which these initiatives were undertaken by Town Councils. On the whole, public incubators provide $0.1 \%$ of the total number of Valencian-Community-based firms and $0.05 \%$ of social security contributors, which quantitatively represents a low impact on the territory where their action develops.

The ranking-style report over a census of 353 business incubators published by FUNCAS (Fundación de las Cajas de Ahorro de España [Foundation of Spanish Savings Banks]) (Blanco Jiménez et al. 2016), stresses the fact that, despite the constant increase in the number of business incubators in Spain, they find themselves in very different management and development situations: from those that are mere lessors of cheap offices to the ones which deliver a far-reaching service to the incubated firms, managing to achieve a high survival rate amongst their associates. According to this study, $42.9 \%$ of business incubators offer com plete services (advice, monitoring, etc.) as opposed to the remaining $57.1 \%$, which essentially provide a cheap location and an infrastructure to start operating. Nevertheless, the report also highlights the best quality of incubators, namely 'their capacity to reduce the mortality rate of national firms'.

The proliferation of incubators has favoured the interest raised by these facilities both amongst public administrations, such as the Diputación de Barcelona (Provincial Government of Barcelona) (2015) to quote but one example, and within the academic world. Thus, giving rise to the publication of best practice manuals as well as reports about their performance, or trying to examine the role performed by incubators in economic development. It is not until the last few years, though, that attention has been focused on dealing with the issue of efficiency, understood as the ability to perform properly or fulfil a particular function, and the economic - 
particularly social- profitability of business incubators.

\section{Proposal for a method to measure business incubator profitability}

This section lists the main characteristics of the models examined that will provide us with the foundations for the design of the method suggested here to measure the profitability of business incubators.

\subsection{EU's guide to cost-benefit analysis}

The closest reference is the 'Guide to cost-benefit analysis of investment projects' established for investments in industrial estates and technological parks (European Union 2003). This guide describes the steps to be taken for an effective assessment, amongst other things, of the investments which could be carried out in the creation of centres focused both on promoting new enterprises and on giving support to already existing ones (technological parks or business innovation centres). A proposal is made for an analysis that can predict revenues (via rental or the assignment of grounds and warehouses, and the sale price for basic services: water, electricity, sewer and treatment systems, storage, logistics, etc.), real services and management costs (costs of goods and services needed for the operation of an infrastructure and the production of actual services) within a time frame of at least 20 years.

The economic analysis will have to consider both the social benefits and their quantification, the economic cost of the raw materials, and grounds used to implement the project. Also assessing the staff costs, in accordance with the loss that not using them for an alternative optimum use entails for society, along with the environmental costs that will be incurred in construction.

\subsection{Social Cost-Benefit Analysis (SCBA)}

The theoretical grounds for this analysis can be found in Welfare Economy (Pigou, 2013), a branch of economic analysis focused on the formulation of ethical propositions which can prove useful to determine the convenience of a specific policy or a particular resource allocation scheme.

The implementation of this analysis, especially utilised in the field of road and railway networks, pursues as its goal to increase social welfare, promoting an efficient allocation of 
resources. This is why it should be considered a helpful instrument to make decisions about previously adopted alternatives, and not about projects already in progress, as is the case under study, with business incubators operating since the 1990s. One of the main limitations of this technique lies in the problems associated with the prediction and monetary valuation of external effects, a high degree of accuracy and consistency being required for its application. However, this method has the virtue of avoiding an inefficient allocation of public resources, (De Rus 2009).

\subsection{Social Return on Investment (SROI)}

SROI is a method based on the principles of understanding, measurement, and communication of extra-financial value: the social value which is currently not reflected in conventional financial accounts, in relation to the resources invested. Developed from a traditional cost-benefit analysis and social accounting, SROI constitutes a participatory approach which allows to capture, in monetary terms, the value of a wide range of results, regardless of whether or not they have a market value.

The SROI analysis tells us how an organisation, programme, project, initiative, etc., creates value (Theory of Change [Connell and Kubisch 1998]) and produces a coefficient that indicates the proportion of total value in euros created for each euro invested. It is a tool for making decisions based on the optimisation of a project's social and labour impacts. This methodology, created by George R. Roberts within the Roberts Enterprise Development Fund (REDF) organisation in San Francisco in 1997, has as its aim to assess the investments in business initiatives made for the purpose of achieving the social and labour insertion of social groups at risk of exclusion (Bugg-Levine and Emerson 2011). It was revised by the NEF (New Economics Foundation) in 2000 with the collaboration of UK public administrations. Currently, the methodology is widely utilised to measure the social return of public subsidies amongst public administrations (ECODES 2013). M ore modern studies, such as the one written by Nicholls et al. (2009), refer to various typologies within the nature of the SROI analysis, drawing a distinction between an 'evaluative' aspect -based on outcomes that have already taken place over the history of the evaluated element- on one side, and what is termed as 'prospective' or forecast value, which makes it possible to predict how much social value will be created if the expected outcomes are obtained, on the other. 
As can be seen, most of the methods implemented to measure profitability start from the cost-benefit analysis. The key aspect, when it comes to incubators, lies in monetising their results as opposed to the expenses incurred to ensure their operation. Thus, allowing the entities, which allocate money resources, to cover the expenses required for their maintenance (property investment and amortisation, operational expenses and expenses related to the incubator's staff, etc.) can return the investment made to the coffers of public administrations through the collection of taxes and social security contributions of both the workers of the incubator and the entrepreneurs accommodated therein. Therefore, if the total revenues exceed the expenses, it will be possible to state that the incubator is economically profitable, which consequently allows us to suggest that it is socially profitable too, insofar as it represents a net contribution to the Public Administration.

The difficulty in applying a specific method which can efficiently assess return on investment, firstly, stems from the lack of a standard model to measure business incubator profitability (Ferreiro Seoane 2014). The proposal made by the European Commission (2010) for public investment projects in general -and not for the specific case of business incubatorsconsists in obtaining the monetised value from the quotient between the expenses incurred by incubators and the jobs created in order to know the cost of each new job. In turn, InBIA (International Business Innovation Association) additionally includes a comparison of the subsidies received by the incubator and the number of accommodated and post-incubated firms, using the taxes and social security contributions both of the firms accommodated at the incubator and of their employees (Ortega Cachón 2012).

Our method to measure social profitability will be determined by two factors:

1. Firstly, because of the type of assessment that is seen as better suited for its application to business incubators, we consider two types of approaches:

a. An internal evaluation will be performed through the implementation of a cost-benefit analysis allows to obtain cash flows, from which indicators will be obtained serving to quantify economic profitability.

b. Conversely, a global evaluation will carry out this assessment, but will cover, via taxes, the impact caused by the action of incubators and their enterprises on every administration, which will help us quantify their social impact beyond the individual profitability of each incubator. 
2. Secondly, these issues will be addressed depending on the availability and validity of the information that needs to be obtained as well as on its treatment, together with the inclusion, or exclusion, of public aids and subsidies.

Taking as a reference the two works which have most thoroughly examined the phenomenon of business incubators in Spain, applying their specific methodologies, more similarities than differences can be seen between the two:

1. The first and best-known method is the one proposed by Ortega Cachón (2012) in his doctoral thesis 'M easurement of socioeconomic impact and assessment of policies focused on supporting entrepreneurs and boosting firm creation.' Ortega Cachón (2012) utilises the return on investment (ROI) method which is obtained from comparing negative and positive flows over 10 years, where the negative flows are represented by the public investment needed to implement a network of six business incubators in the city of Madrid. Whereas the positive ones correspond to the turnover of new firms that have helped prevent the closure of incubators, which in turn implies giving its contributions back to the Public Administration via tax revenues (through the payment of taxes).

2. The second strategy, used by Ferreiro Seoane (2014) in his doctoral thesis 'Business incubators in Galicia: a wealth-generating strategy,' proposes a new method (the fiscal balance applied to business incubators) from two distinct methodologies which cannot be individually applied to the case of business incubators, but which jointly imply an approach that provides interesting results through a calculation based on a twofold complementary perspective: (a) Fiscal Balance of Autonomous Communities (Regions), whose purpose consists in identifying the balance that the total expenses incurred by the Central Administration implied for a specific Autonomous Community minus the amount which that Community provides to the coffers of Public Treasury; and (b) the guide to the cost-benefit analysis of European Commission's investment projects previously described. Ferreiro Seoane (2014), on the one hand, pays attention to the revenues collected by the Administration both through direct taxes (as is the case of VAT) and through indirect ones (Corporate Tax and contributions to Social Security) generated by the creation of firms and, on the other hand, compares them with the costs linked to incubator operation and maintenance over a five-year scenario.

The ROI method implemented by Ortega Cachón (2012) materialises in the generation of a ratio which results from the quotient between total revenues (associated with taxes and payment of rentals) and total expenses (investment made in the incubator and its maintenance). 
Also resulting from the fiscal balance developed by Ferreiro Seoane (2014), although closer to the Social Cost-Benefit Analysis model (Azqueta 2002), it starts from the quotient or from the balance generated between the public resources available to develop the activity of incubators (public contributions and subsidies, along with property amortisations) and the tax revenues generated by workers and entrepreneurs.

Both methods have the same purpose: determining how many euros society obtains for each euro invested. The difference clearly lies in the way of counting the investment concepts and items, expenses and revenues, and in whether public aids are included or not. Furthermore, and more precisely with regard to ROI calculation, Ortega Cachón (2012), not only takes into account the tax revenues from incubator workers and from the firms currently accommodated in the incubators, but also those corresponding to post-incubated firms. What both methods have in common is the fact that they do not include other taxes such as the Spanish Business Activities Tax of firms in the calculation. The reason being that none of the firms accommodated and incorporated as business organisations in these two studies have a turnover exceeding $1,000,000$ euros. The same applies to the Property Tax because most incubators are exempted from paying it.

Following the recommendation of the Spanish Ministerio de Fomento (Ministry of Development) and in its general conception, investment profitability will consist in measuring the rate of recovery for the investment made in business incubators from revenue generation, ultimately using profitability measurement indicators such as the Internal Return Rate (IRR), the Net Present Value (NPV) or the Cost/Benefit Ratio (CBR).

As for the case examined in the present research work -public business incubators located in the Valencian Community- a decision was made to adopt a methodology which can combine the methods described above, and which is summarized in Table 1, in such a way that:

- The system applied to Social Return on Investment (SROI) is implemented, paying special attention to the assessments and opinions of incubator users (entrepreneurs);

- This is complemented with the information associated with the Fiscal Balance method in those indicators where valid information can be obtained. In this respect, an effort will be made to determine the economic and social profitability of incubators, as well as the efficiency of the resources available, by means of the scheme proposed in Table 1.

Table 1. Cost-benefit analysis: methods to calculate the profitability of Spanish business incubators 


\begin{tabular}{|c|c|c|}
\hline \multirow[b]{2}{*}{ Cost/ benefit } & \multicolumn{2}{|c|}{ Methods } \\
\hline & ROI & Fiscal Balance \\
\hline \multirow{4}{*}{$\begin{array}{l}\text { Costs or public } \\
\text { resources } \\
\text { allocated }\end{array}$} & $\begin{array}{l}\text { Investment expenses: outlay made by the } \\
\text { entity that owns the incubator in its building } \\
\text { and maintenance }\end{array}$ & $\begin{array}{l}\text { Annual amortisation of the costs associated with } \\
\text { the construction and equipment of the } \\
\text { incubator }\end{array}$ \\
\hline & \multicolumn{2}{|c|}{$\begin{array}{c}\text { M aintenance and/or running expenses: amount of the annual contracts for cleaning, security, } \\
\text { miscellaneous supplies and management of incubators }\end{array}$} \\
\hline & \multicolumn{2}{|c|}{ Salary expenses corresponding to the workers employed in the incubators } \\
\hline & $\mathrm{NC}$ & $\begin{array}{l}\text { Subsidies and/or contributions of entities } \\
\text { allocated to incubator maintenance }\end{array}$ \\
\hline \multirow{5}{*}{$\begin{array}{l}\text { Profits or } \\
\text { revenues } \\
\text { generated } \\
\text { through the } \\
\text { activity } \\
\text { developed by } \\
\text { the incubator }\end{array}$} & \multicolumn{2}{|c|}{ Income Tax and Social Security contributions of the firms accommodated in the incubator } \\
\hline & $\begin{array}{l}\text { Income Tax and Social Security contributions } \\
\text { of post-incubated firms }\end{array}$ & $\mathrm{NC}$ \\
\hline & \multicolumn{2}{|c|}{ Income Tax and Social Security contributions of incubator workers } \\
\hline & \multicolumn{2}{|c|}{ Corporate Tax } \\
\hline & $\begin{array}{c}\text { Turnover of accommodated firms: VAT } \\
\text { charged }\end{array}$ & NC \\
\hline
\end{tabular}

Source: Elaborated by the authors

\section{Methodology}

The procedure suggested to carry out the research work consisted in preparing a census of all the active business incubators located in the Valencian Community -a south-eastern Spanish region made up of three provinces (Alicante, Valencia, and Castellón) with 5 million inhabitants and 542 municipalities. The competencies related to economic and industrial promotion, as well as the actions oriented to employment generation, fall upon the Generalitat Valenciana (Autonomous Regional Valencian Government) -and not upon the Central State. It is the fourth Spanish region in terms of GDP generation, its main productive sectors being: agriculture (basically around citrus fruit growing); industrial (footwear, toys, textiles, ceramics, chemicals and an important car-manufacturing plant); and an incipient culture in favour of innovative enterprises under the auspices of Technological Institutes and Universities.

The information needed to develop our study was obtained in two stages: (1) qualitative; and (2) quantitative. The technique used to collect information during the qualitative stage was an in-depth interview carried out face to face or through the telephone (in the case of the province of Castellón) with the directors and/or managers of the 43 incubators existing in the 
Valencian Community. Two of them were not available, and one did not complete properly the survey questionnaire that we sent to him, which means that our information refers to a total population of 40 from the 43 incubators (93.02\%).

The information obtained in the quantitative study stems from a closed-question survey addressed to the business projects leaders and to the directors or managers of the firms currently accommodated in the incubators, for which purpose an online questionnaire was used. The interest during this second stage focuses on discovering the profile of the entrepreneur accommodated in the incubators (which is beyond the scope of the present paper) but also in comparing the opinions expressed by the directors and managers. Seeking to carry out a qualitative analysis of incubators, a process was undertaken that led to the identification of 394 firms accommodated in incubators, of which 183 answered the survey (statistical error $+/-5.5$, confidence interval $95.5 \%$, and $p=q=0.5$ ). The information from these firms accommodated in incubators helped us to confirm the data provided in the qualitative phase. When not all the information we needed was available in these cases, we then resorted to secondary information sources (databases, reports, previous studies, web pages or websites, etc.), which allowed for the completion of the information and the development of estimates and assessments in a more accurate manner.

\section{Results}

\subsection{Profit and Loss Accounts}

The necessary financial resources for the incubators to provide an adequate service to entrepreneurs are composed of two large groups: 1) On the one hand, three items of expenses, such as staff costs, operating expenses, and depreciation applied to the buildings where the incubators are located; 2) On the other hand, two items of income, which include the entrepreneurs' monthly charges for housing in accommodation expenses and contributions of the entity owners, as well as public assistance or subsidies.

The incubators managed a spending budget of 2,181,670€ in 2014. The main expense (43.6\%) came from the wages of workers, followed by operating expenses (33.0\%), and thirdly by depreciation (23.4\%). Regarding income, $53.8 \%$ of the expenses were covered by the rentals of entrepreneurs and $46.2 \%$ through grants and/ or contributions from entity owners. Naturally, 
the size of the incubator, the workforce, and its range of accommodation and services generates substantial differences by the ownership, provincial, and sectoral focus of the incubator.

The analysis of the profit and loss account (see Table 2) made it clear that no incubator can balance its accounts without the contributions of the entities owning them and without public aids and subsidies. This should come as no surprise, since one of the advantages (though probably not the most important one, as previously seen) of incubators lies in the fact that they offer users a facility at a low cost, which implies taking the cost charged to users of a market price or to a price below market value. Furthermore, being public bodies (38.5\% of incubators are publicly owned -universities and town councils- with the ownership of the other $61.5 \%$ corresponding to private entities, namely: chambers of commerce and European Business Innovation Centres [BICs]), they either required in the past or currently require public financial aids for their construction, management, and maintenance. As previously established, even though they do not pursue an economic return -because they are non-profit bodies- they do try to ensure that their activity will not generate an unnecessary cost to the coffers of public administrations. The objective consists in enabling these incubators to generate an action which can indirectly return the invested resources to society via taxes. 
Table 2. Profit and loss account of incubators located in the Valencian Community by province, ownership and sectoral group (euros and \% over expenses) for 2014

\begin{tabular}{|c|c|c|c|c|c|c|c|c|c|c|c|c|}
\hline \multirow[t]{3}{*}{ Incubators } & & \multicolumn{7}{|c|}{ Expenses and investment amortisation } & \multicolumn{4}{|c|}{ Revenues } \\
\hline & & \multicolumn{2}{|c|}{ Staff } & \multicolumn{2}{|c|}{ Operational } & \multicolumn{2}{|c|}{ Amortisations } & \multirow{2}{*}{$\begin{array}{c}\text { Total } \\
€\end{array}$} & \multicolumn{2}{|c|}{ Accommodation } & \multicolumn{2}{|c|}{ Contributions/subsidies } \\
\hline & & $€$ & $\%$ & $€$ & $\%$ & $€$ & $\%$ & & $€$ & $\%$ & $€$ & $\%$ \\
\hline \multirow{5}{*}{ Alicante } & Town Councils & 129,498 & 38.8 & 100,179 & 30.0 & 104,095 & 31.2 & 333,772 & 207,709 & 62.2 & 126,063 & 37.8 \\
\hline & $\begin{array}{l}\text { Chambers of } \\
\text { Commerce }\end{array}$ & 155,350 & 34.6 & 108,699 & 24.2 & 184,381 & 41.1 & 448,430 & 277,260 & 61.8 & 171,170 & 38.2 \\
\hline & European BICs & 77,500 & 41.4 & 97,000 & 51.8 & 12,606 & 6.7 & 187,106 & 75,211 & 40.2 & 111,895 & 59.8 \\
\hline & Universities & 196,905 & 58.6 & 112,500 & 33.5 & 26,750 & 8.0 & 336,155 & 200,072 & 59.5 & 136,083 & 40.5 \\
\hline & Alicante & 559,253 & 42.8 & 418,378 & 32.0 & 327,832 & 25.1 & $1,305,463$ & 760,252 & 58.2 & 545,211 & 41.8 \\
\hline \multirow{4}{*}{ Castellón } & Town Councils & 48,000 & 34.5 & 51,000 & 36.7 & 40,000 & 28.8 & 139,000 & 34,637 & 24.9 & 104,363 & 75.1 \\
\hline & $\begin{array}{l}\text { Chambers of } \\
\text { Commerce }\end{array}$ & 24,150 & 35.9 & 15,605 & 23.2 & 27,500 & 40.9 & 67,255 & 33,600 & 50.0 & 33,655 & 50.0 \\
\hline & European BICs & 45,000 & 48.6 & 40,000 & 43.2 & 7,500 & 8.1 & 92,500 & 51,408 & 55.6 & 41,092 & 44.4 \\
\hline & Castellón & 117,150 & 39.2 & 106.605 & 35.7 & 75,000 & 25.1 & 298,755 & 119,645 & 40.0 & 179,110 & 60.0 \\
\hline \multirow{5}{*}{ Valencia } & Town Councils & 78,079 & 61.4 & 41,380 & 32.5 & 7,713 & 6.1 & 127,172 & 21,122 & 16.6 & 106,050 & 83.4 \\
\hline & $\begin{array}{l}\text { Chambers of } \\
\text { Commerce }\end{array}$ & 74,000 & 31.9 & 79,315 & 34.2 & 78,930 & 34.0 & 232,245 & 125,904 & 54.2 & 106,341 & 45.8 \\
\hline & European BICs & 66,500 & 47.0 & 60,000 & 42.4 & 15,000 & 10.6 & 141,500 & 90,720 & 64,1 & 50,780 & 35.9 \\
\hline & Universities & 57,200 & 74.7 & 15,637 & 20.4 & 3,698 & 4.8 & 76,535 & 57,539 & 75.2 & 18,996 & 24.8 \\
\hline & Valencia & 275,779 & 48.0 & 196,332 & 33.9 & 105,341 & 18.1 & 577,452 & 295,285 & 46.9 & 282,167 & 53.1 \\
\hline Ownership & Town Councils & 255,577 & 42.6 & 192,559 & 32.1 & 151,808 & 25.3 & 599,944 & 263,468 & 43.9 & 336,476 & 56.1 \\
\hline
\end{tabular}


Table 2. Profit and loss account of incubators located in the Valencian Community by province, ownership and sectoral group (euros and \% over expenses) for 2014

\begin{tabular}{|c|c|c|c|c|c|c|c|c|c|c|c|c|}
\hline \multirow{3}{*}{\multicolumn{2}{|c|}{ Incubators }} & \multicolumn{7}{|c|}{ Expenses and investment amortisation } & \multicolumn{4}{|c|}{ Revenues } \\
\hline & & \multicolumn{2}{|c|}{ Staff } & \multicolumn{2}{|c|}{ Operational } & \multicolumn{2}{|c|}{ Amortisations } & \multirow{2}{*}{$\begin{array}{c}\text { Total } \\
€\end{array}$} & \multicolumn{2}{|c|}{ Accommodation } & \multicolumn{2}{|c|}{ Contributions/subsidies } \\
\hline & & $€$ & $\%$. & $€$ & $\%$. & $€$ & $\%$. & & $€$ & $\%$. & $€$ & $\%$. \\
\hline & $\begin{array}{l}\text { Chambers of } \\
\text { Commerce }\end{array}$ & 253,500 & 33.9 & 203,619 & 27.2 & 290,811 & 38.9 & 747,930 & 436,764 & 58.4 & 311,166 & 41.6 \\
\hline & European BICs & 189,000 & 44.8 & 197,000 & 46.8 & 35,106 & 8.4 & 421,106 & 217,339 & 51.6 & 254,262 & 48.4 \\
\hline & Universities & 254,105 & 61.6 & 128,137 & 31.0 & 30,448 & 7.4 & 412,690 & 257,611 & 62.4 & 155,079 & 37.6 \\
\hline \multirow[t]{3}{*}{ Sectoral group } & G1 Techno. & 491,105 & 50.4 & 376,137 & 38.6 & 105,554 & 11.0 & 972,796 & 508,587 & 52.3 & 463,209 & 47.7 \\
\hline & G2 Indust. & 91,498 & 28.0 & 75,621 & 23.1 & 159,579 & 48.8 & 326,698 & 267,948 & 82.0 & 58,750 & 18.0 \\
\hline & G3 Servic. & 369,579 & 41.9 & 269,557 & 30.6 & 243,040 & 27.6 & 882,176 & 397,647 & 45.1 & 484,529 & 54.9 \\
\hline \multicolumn{2}{|l|}{ Total } & $952,182 €$ & $43.6 \%$ & $721,315 €$ & $33.0 \%$ & $508,173 €$ & $23.4 \%$ & $2,181,670 €$ & $1,175,182 €$ & $53.8 \%$ & $1,056,984 €$ & $46.2 \%$ \\
\hline
\end{tabular}

Source: Elaborated by the authors

The incubators ESPAITEC and CREIX were not included because no information was available about them.
Comentado [J A1]: You use Red Font Color, instead of Black like in Table 3. Verify proper use of color for consistency. 


\subsection{Resources and revenues generated in incubators}

Table 3. Results corresponding to resources and revenues generated by Valencian-Community-based incubators by ow nership and sectoral group for 2014

\begin{tabular}{|c|c|c|c|c|c|c|c|}
\hline \multirow{2}{*}{ Incubators } & & \multicolumn{3}{|c|}{ Income } & \multirow{3}{*}{$\begin{array}{c}\text { Resources } \\
€ \\
336,476 \\
\end{array}$} & \multirow{3}{*}{$\begin{array}{c}\text { Result } \\
€ \\
231,452\end{array}$} & \multirow{3}{*}{$\begin{array}{c}\text { Ratio }=\text { Income } / \text { Resources } \\
1.7 €\end{array}$} \\
\hline & & \multirow{2}{*}{$\begin{array}{c}€ \\
567,928\end{array}$} & \multirow{2}{*}{$\begin{array}{c}\% \\
\text { Work. } \\
9.8 \\
\end{array}$} & \multirow{2}{*}{$\begin{array}{c}\% \\
\text { Firms } \\
90.2\end{array}$} & & & \\
\hline \multirow{4}{*}{ Ownership } & Town Councils & & & & & & \\
\hline & $\begin{array}{l}\text { Chamber of } \\
\text { Commerce }\end{array}$ & $1,092,810$ & 4.3 & 95.7 & 311,166 & 781,644 & $3.5 €$ \\
\hline & European BICs & 611,507 & 5.5 & 94.5 & 203,767 & 407,740 & $3.0 €$ \\
\hline & Universities & 582,982 & 9.0 & 91.0 & 155,079 & 427,903 & $3.8 €$ \\
\hline \multirow[t]{3}{*}{$\begin{array}{l}\text { Sectoral } \\
\text { Group }\end{array}$} & $\begin{array}{l}\text { G1 } \\
\text { Technological }\end{array}$ & $1,240,132$ & 7.9 & 92.1 & 463,209 & 776,923 & $2.7 €$ \\
\hline & G2 Industrial & 418,962 & 4.7 & 95.3 & 58,750 & 360,212 & $7.1 €$ \\
\hline & G3 Services & $1,196,130$ & 6.0 & 94.0 & 484,529 & 711,602 & $2.5 €$ \\
\hline \multicolumn{2}{|l|}{ Total } & $2,855,226 €$ & $6.6 \%$ & $93.4 \%$ & $1,006,488 €$ & $1,848,738 €$ & $2.8 €$ \\
\hline
\end{tabular}

Source: Elaborated by the authors

Public resources worth $1,006,488 €$ were allocated to operation and equipment expenses by the incubators located in the Valencian Autonomous Region in 2014. A total of $2,855,225 €$ were collected via taxes and social security contributions with a positive result of $1,848,737 €$ or, to put it in another way, using the resources/ revenues ratio, the Administration received $2.8 €$ for each euro invested in a business incubator (see Table 3 ).

Producing a more accurate x-ray of the situation requires an analysis focused on ownership (municipal incubators belonging to Town Councils, Chambers of Commerce, European BICs and university incubators) and sectoral orientation.

Municipal incubators, owned by Town Councils, are the second largest group (13 incubators). Though, they are the ones which offer the worst result $(231,452 €)$. And it is also worth highlighting that six out of seven incubators with a negative result are municipal. The Alicante province is the only one who obtains a positive result $(302,095 €)$, above all, due to the good performance shown by industrial business incubators.

The eighteen incubators owned by the different Chambers of Commerce have the best result as far as ownership is concerned: $781,644 €$ and positive in all three provinces, the second best resources/revenues ratio, $3.5 €$ for each euro invested, as well as the best proportion of generated revenues: $95.7 \%$ come from entrepreneurs' activity. European BICs have the worst 
results $(407,740 €)$ and the lower Income/ Resources ratio. University incubators -or those linked to public universities- form the group with the best performance: $427,903 €$ and a $3.8 €$ ratio.

In regard to sectoral orientation, industrial incubators are the ones providing a better result, insofar as a $7.1 €$ ratio as well as a $95.3 €$ proportion of revenues coming from entrepreneurs is achieved allocating only $6.1 \%$ of the total resources invested. Both technological and service incubators obtain similar results in the indicators utilised.

\subsection{Incubator profitability and effectiveness}

Valencian-Community-based incubators had an economic budget of $1,854,929 €$ at their disposal in 2014, distributed in three large items dedicated to meet their economic needs: staff expenses; running expenses; and amortisations. Precisely $53.2 \%$ of the revenue budget comes from the payments that entrepreneurs are made to pay as accommodation expenses. Being that it was insufficient, and needing to balance their income statement, these public bodies with no obligation to generate economic returns -unlike private enterprises- needed 955,708€ (46.8\% of their budget) coming from public aids and subsidies, as well as contributions made by the very own entities that manage the incubators.

From a merely economic perspective, it becomes clear that incubators cannot be profitable for public administrations without financial aids. However, a holistic assessment which contemplates the return of public investments from the tax collection obtained through the payment of income tax and corporate tax, together with the contributions to social security by incubator workers as well as the entrepreneurs and their employees, does prove their profitability, since they generate a return which exceeds the investments and costs needed to set them in motion. These fiscal instruments made it possible to collect $2,705,357 €$ in 2014 , with a positive result of $1,749,649 €$ and, in terms of the invested resources/ generated revenues ratio, the Administration collected $2.8 €$ for each euro invested. Moreover, the utilisation of a profitability indicator, as is the Net Present Value (NPV) -and from a group of initial investments which in most cases received public subsidies for the building and/or fitting-out of the premises that house business incubators- makes it possible to obtain a positive result of $9,324,928 €$ for a 20-year period ${ }^{4}$.

\footnotetext{
${ }^{4}$ Readers can request for more information about the origin of these data.
} 
However, in the analysis of crossed variables, underlies that a greater contribution of public money in incubators does not generate a higher tax collection. Table 4 shows the correlations between the resources provided, tax revenues, and the business incubators resources. In Table 4, Tax Revenues (1) represent tax collection from entrepreneurs staying in the incubators, Tax Revenues (2) are the tax revenue coming from workers in the incubators, whereas Tax Revenues $(t)$ are the total revenue, the sum of both of them.

The analysis of the bivariate correlation between public resources invested and tax revenues collected reveals a Pearson's coefficient of 0.534 , which shows us that despite the existence of a correlation between variables, it is not a significant one, its generation stemming from the tax revenues associated with the actual incubator workers (via taxes, Social Security) rather than from those collected by entrepreneurs. Nevertheless, the correlation between the private resources of incubators and the tax revenues collected by entrepreneurs shows a strong positive Pearson's correlation coefficient.

The same result is confirmed using a linear regression analysis (represented in Table 5). It cannot be confirmed that a greater injection of public money in business incubators causes an increase in tax revenues to be obtained, as the regression model only explains $12.5 \%$ of the cases. However, the model 'private resources-income revenues' suggests that the higher contribution of private income will provide more tax revenues in exchange, with a probability of $39.9 \%$.

It can therefore be concluded that the business incubators located in the Valencian Community are not economically profitable because they need public aids for their construction, management, and maintenance, although they are indeed socially profitable, insofar as the activity developed by entrepreneurs in these incubators makes it possible to return to the public administrations -via taxes- more than what they invested. 
Table 4. Correlations between resources, tax revenues and results (business incubators Valencian_Community 2014)

\begin{tabular}{|c|c|c|c|c|c|c|c|}
\hline & & Public Resources & Private Resources & Tax Revenues (1) & Tax Revenues (2) & Tax Revenues (t) & Results \\
\hline \multirow{3}{*}{ Public Resources } & Pearson Correlation & 1 & 0.300 & $0.714 * *$ & 0.297 & $0.354 *$ & 0.006 \\
\hline & Sig. (bilateral) & & 0.071 & 0.000 & 0.074 & 0.029 & 0.970 \\
\hline & $\mathrm{N}$ & 38 & 37 & 38 & 37 & 38 & 38 \\
\hline \multirow{3}{*}{$\begin{array}{l}\text { Private Resources } \\
\text { (ącommodations) }\end{array}$} & Pearson Correlation & 0.300 & 1 & $0.751^{* *}$ & $0.599 * *$ & $0.632^{* *}$ & $0.560 * *$ \\
\hline & Sig. (bilateral) & 0.071 & & 0.000 & 0.000 & 0.000 & 0.000 \\
\hline & $\mathrm{N}$ & 37 & 37 & 37 & 37 & 37 & 37 \\
\hline \multirow[t]{3}{*}{ Tax Revenues (1) } & Pearson Correlation & $0.714^{* *}$ & $0.751^{* *}$ & 1 & $0.524 * *$ & $0.588^{* *}$ & $0.363^{* *}$ \\
\hline & Sig. (bilateral) & 0.000 & 0.000 & & 0.001 & 0.000 & 0.025 \\
\hline & $\mathrm{N}$ & 38 & 37 & 38 & 37 & 38 & 38 \\
\hline \multirow[t]{3}{*}{ Tax Revenues (2) } & Pearson Correlation & 0.297 & $0.599 * *$ & $0.524 * *$ & 1 & $0.998 * *$ & $0.950 * *$ \\
\hline & Sig. (bilateral) & 0.074 & 0.000 & 0.001 & & 0.000 & 0.000 \\
\hline & $\mathrm{N}$ & 37 & 37 & 37 & 37 & 37 & 38 \\
\hline \multirow[t]{3}{*}{ Tax Revenues (t) } & Pearson Correlation & $0.354 *$ & $0.632 * *$ & $0.588^{* *}$ & $0.998^{* *}$ & 1 & $0.938^{* *}$ \\
\hline & Sig. (bilateral) & 0.029 & 0.000 & 0.000 & 0.000 & & 0.000 \\
\hline & $\mathrm{N}$ & 38 & 37 & 38 & 37 & 38 & 38 \\
\hline \multirow[t]{3}{*}{ Results 2014} & Pearson Correlation & 0.006 & $0.560 * *$ & $0.363^{* *}$ & $0.950^{* *}$ & $0.938 * *$ & 1 \\
\hline & Sig. (bilateral) & 0.970 & 0.000 & 0.025 & 0.000 & 0.000 & \\
\hline & $\mathrm{N}$ & 38 & 37 & 38 & 38 & 38 & 38 \\
\hline
\end{tabular}

** Signification level- 0.01 (bilateral). * Signification level- 0.05 (bilateral).

Source: Elaborated by the authors 
Table 5. Regression analysis: public and private economic resources, total tax revenues

\begin{tabular}{l|l|l|c|c}
\hline & $\begin{array}{l}\text { Standard } \\
\text { Coefficients } \\
\text { (Beta) }\end{array}$ & T(Sig.) & $\mathrm{R}^{2}$ & $\begin{array}{l}\text { Corrected } \\
\mathrm{R}^{2}\end{array}$ \\
\hline $\begin{array}{l}\text { Model 1: Public } \\
\text { Resources }\end{array}$ & 0.354 & $\begin{array}{l}2.271 \\
(0.029)\end{array}$ & 0.125 & 0.101 \\
\hline $\begin{array}{l}\text { Model 2: Private } \\
\text { resources }\end{array}$ & 0.632 & $\begin{array}{l}4.823 \\
(0.000)\end{array}$ & 0.399 & 0.382 \\
\hline
\end{tabular}

Source: Elaborated by the authors

Information about the incubators under analysis, referring to the number of jobs created, can be viewed in the APPENDIX. Using the average jobs generated per incubator as a boundary line, fifteen incubators are above this indicator. Six of them public: three municipal ones in the province of Alicante and another three linked to universities. And the remaining nine private: the four European BICs, and five owned by the chambers of commerce. In terms of sectoral orientation, the most efficient ones are the technological incubators with six (75\% of the total), followed at a great distance by those belonging to chambers of commerce with 5 (27.7\%) and the municipal ones with 3 (23.0\%).

\section{Discussion and Conclusion}

This study has allowed us to verify that business incubators are not economically profitable, at least in the case of the Valencian Community (Spain). Several circumstances enable us to confirm such a conclusion, the most relevant one being their nature and origin, linked to a number of financial aids, which sought to place at the disposal of especially innovative new firms a location below price market value so that they could start their business activity. This 'low cost' idea is based on a Spanish (and previously European) culture with a clear subsidising inspiration: the principle that it was necessary to offer something sufficiently attractive from the point of view of costs for users which could raise an additional interest amongst potential entrepreneurs, encouraging them to set up a firm. From here, the lower cost for the firms accommodated in incubators actually meant a larger budget allocation by the promoting entities to maintain the facilities.

The situation of public administrations is certainly far from promising -with no significant improvements being expected in the near future- but the technical contribution made by incubator staff proved relevant for the entrepreneurs welcomed therein, who have shown their interest in having better advisors with a more permanent presence in the incubator. Consequently, this why there should be greater monitoring of the staff serving firms, especially 
everything that has to do with their qualification and technical reliability. The multiplier impact of a correct guidance is high enough to make it necessary for incubators to have either specialised staff or outsourced services that can fulfil that function. It also becomes necessary to put forward a specific update training programme for business incubator managers that can keep these professionals permanently informed about the latest trends in everything that surrounds the creation of innovative firms, and with sectoral specialisations.

Notwithstanding, the social impact assessed from the effect of taxation on the different public administrations, allows us to assert on a general basis that firm creation already generates a positive effect on the business environment where it takes place: obviously not so much from a quantitative point of view (the number of enterprises created in proportion with those created outside incubators is very small). In particular, the contribution of incubators to newly-created firms must not be seen as an expense but as an investment that will eventually generate returns, because the allocation of public funds to properly managed projects is bound to produce a middle- and long-term positive result, materialised in $2.8 €$ for each euro invested, in the case of the incubators analysed in the present paper.

It is striking that a higher economic contribution by the entities running the incubators does not guarantee that more compensatory tax revenues will be generated; instead, it is the greater generation of revenues through the contributions of accommodated enterprises that shows a closer link to tax revenues in the future.

With regard to the historical analysis of profit and loss accounts shown by business incubators, it became clear that a better management in incubators, especially derived from an increase in private revenues (coming from the entrepreneurs accommodated in incubators), implies a higher degree of firm and job creation. This conclusion leads us to suggest a proactive management of incubators, where their managers should be encouraged to promote initiatives that can improve revenues via incubated firms, since that entails, amongst other things, higher numbers of hired staff.

Similarly, the greater presence of incubator staff does not guarantee the creation of more firms, which means that the functions of business incubator managers or experts still have a long way to go. If the incubators are presented as a space for services where the latter are precisely labour-intensive, the qualification of labour force should acquire a prominent role that, the statistics show, it does not currently have. 
A relevant factor when it comes to incubators is the fact that they are oriented towards firms with an above average volume of innovative components. This implies recognising that incubators have a strong attraction potential for a certain typology of firms, such as those related to information and communications, as well as professional, scientific and technical activities. It seems logical to suggest that a society which advocates changes of economic paradigms and models should favour elements that can boost such activities from the public administration. Assuming the hypotheses posed by Stiglitz (1992) about the intervention of the public administration in the private sector, it would be completely justified to devote a greater volume of public resources to promote the creation of more innovative enterprises (Hjorth 2013; Steyaert and Katz 2004).

The opinion of incubator users studied and analysed from various perspectives, of both their managers and their beneficiaries, sheds light on the competitive advantages brought by incubators according to the people who work therein every day. And the results of this study show that a better impression exists about those incubators which are more equipped, as far as human resources and services are concerned. This impression is reflected on the high survival rates of firms accommodated in incubators, something that goes perfectly well with the return of the investments made via taxes from firms both when they are inside the incubator and, especially, after having left it.

Finally, it seems to us that a reflection should be performed on the methodology followed to assess social profitability. After all, unlike other studies, ours suggests a methodology by means of reconciling the period during which expenses are generated (which additionally becomes redefined after incorporating the concept of amortisations) with the period corresponding to revenues in such a way that an economic adjustment takes place which is coherent in time.

Apart from the aforementioned, some margin still exists to improve the social impact of business incubators on their environment, therefore, opening new research avenues. An improvement in their management should help create a higher number of firms as well as a better development thereof, which is bound to generate a growing social impact, facilitating the attraction of new enterprises in strategic sectors. Business incubators are able to contribute to the improvement and specialization of strategic sectors that must be previously defined by the governing bodies (political agents) of each territory. It would therefore be interesting to analyse the link between these governing entities and the incubators, so that the services that are most in demand may be properly defined and prevent the incubators from remaining consigned to 
the role of mere estate agents of the hosting companies. All of these constitute reference elements that need to be studied more deeply.

The present paper has a variety of limitations, such as the mainly descriptive approach applied to the treatment of data -being restricted to a single region- which makes it difficult to generalise such data, as well as the difficulty in collecting data from the incubator managers and incubator users -a problem that we tried to solve resorting to secondary sources. In any case, it is our conviction that this paper shows a number of important consequences, both for the public administrations that finance business incubators and for the directors and managers of the latter, as well as for the entrepreneurs who decide to settle down in those incubators. Therefore, our study will hopefully represent a useful contribution to this interesting line of research within the areas of firm creation and local development.

\section{References}

Aerts, K.; Matthyssens, P. and Vandenbempt, K. 2007. «Critical role and screening practices of European business incubators». Technovation. 27(5): 254-267.

Al-M ubaraki, H. M. and Busler, M. 2011. «The Development of Entrepreneurial Companies through Business Incubator Programs». International Journal of Emerging Sciences. 1(2): 95-107.

Al-M ubaraki, H.M . and Wong, S.F. 2011. «How Valuable Are Business Incubators? an Illustration of Their Performance Indicators». In European, Mediterranean \& Middle Eastern Conference on Information Systems. Athens. Greece:756-65.

Azqueta, D. 2002. «Introducción a la economía ambiental». M cGraw-Hill. M adrid.

Bigliardi, B., Dormio, A. I., Nosella, A., and Petroni, G. (2006). «Assessing science parks' performances: directions from selected Italian case studies». Technovation. 26(4): 489-505.

Blanco Jiménez, F.J.; De Vicente Oliva, M .A.; Manera Bassa, J. and Polo Garcia-Ochoa, C. 2016. «Los servicios que prestan los viveros de empresas en España. Ranking 2015». Funcas. Madrid.

Bugg-Levine, A. and Emerson, J. 2011. «Impact investing: Transforming how we make money 
while making a difference». Innovations. 6(3): 9-18.

Byus, K., Deis, D., and Ouyang, B. (2010). «Doing well by doing good: Corporate social responsibility and profitability». SAM Advanced Management Journal. 75(1): 44-55.

Canales García, R.A. and Vergara González, R. 2013. «M ethodological proposal for the study of business incubators based on Social Network Analysis (SNA) and knowledge networks: the case of the UAEM ex». Acta Universitaria. 23(2):27-37.

European Commission. 2004. «El programa europeo a favor del espíritu empresarial». Internet document. http:// www.oei.es/ etp/plan_accion_emprendedores.pdf

European Commission. 2010. «The Smart Guide to Innovation Based Incubators (IBI)». Internet Document.

http://ec.europa.eu/regional_policy/en/information/ publications/ evaluations-guidancedocuments/2010/the-smart-guide-to-innovation-based-incubators-ibi

Connell, J. P. and Kubisch, A. C. 1998. «Applying a theory of change approach to the evaluation of comprehensive community initiatives: progress, prospects, and problems». New approaches to evaluating community initiatives. 2(15-44).

D'Agostino, C. F. 2009. «The Business Incubator on Wheels». Economic Development Journal. 8(4):25-31.

De Marco, S. and Sorando, D. 2015. "Juventud Necesaria. Consecuencias económicas y sociales de la situación del colectivo joven". Consejo de la Juventud de España. Internet document. http:// www.juventudnecesaria.es/wp-content/ uploads/2015/02/]UVENTUD-NECESARIAInforme-completo.pdf

De Rus, G. 2009. «La medición de la rentabilidad social de las infraestructuras de transporte». Investigaciones regionales. 14: 187-210.

Diputación de Barcelona. 2015. «Vivarium: Criterios para la planificación, programación, diseño y construcción de viveros, centros y hoteles de empresa». Internet document. http:// www1.diba.cat/ uliep/pdf/55500.pdf

ECODES. 2013. «Retorno Social de la Inversión (SROI)». Internet document. http:// ecodes.org/ responsabilidad-social/retorno-social-de-la-inversion-sroi\#.VIWIPkvfcs.

Fernández Martínez, P. et al. 2011. «El papel de los Viveros de empresa en la creación de 
empleo». Universidad Rey Juan Carlos. Madrid.

Ferreiro Seoane, F.J. 2014. «Los Viveros de empresas en Galicia: una estrategia generadora de riqueza». Universidade da Coruña. Internet Document. http:// dialnet.unirioja.es/servlet/tesis? codigo $=41063$.

Ferreiro Seoane, F.J. and Vaquero García, A. 2010. «La importancia de los Viveros de empresa como elementos de promoción económica en Galicia». Internet Document. http://alberto.vaquero.webs.uvigo.es/docs/viveros_promocion.pdf

Grinols, E. L., and Mustard, D. B. (2001). «Business profitability versus social profitability: Evaluating industries with externalities, the case of casinos». Managerial and Decision Economics. 22(1-3): 143-162.

Hackett, S. M ., and Dilts, D. M. (2008). «Inside the black box of business incubation: Study Bscale assessment, model refinement, and incubation outcomes». The Journal of Technology Transfer. 33(5): 439-471.

Hjorth, D. 2013. Public entrepreneurship: Desiring social change, creating sociality. Entrepreneurship \& Regional Development. 25(1-2): 34-51.

Kerr, J. E. (2007). Sustainability M eets Profitability: The Convenient Truth of How the Business Judgment Rule Protects a Board's Decision to Engage in Social Entrepreneurship. Available at SSRN 1296270.

Lorentzen, A. (2008). Knowledge networks in local and global space. Entrepreneurship \& Regional Development. 20(6): 533-545.

Lundström, A., Vikström, P., Fink, M., Meuleman, M., Głodek, P., Storey, D., and Kroksgård, A. (2014). «Measuring the costs and coverage of SME and entrepreneurship policy: a pioneering study». Entrepreneurship Theory and Practice. 38(4): 941-957.

Marchis, G. 2011. «Fundamentals of Business Incubator Development». EIRP Proceedings. Internet Document. http://www.proceedings.univdanubius.ro/index.php/ eirp/article/ download/955/874.

Marimon Viadiu, F., and Alonso Martínez, J. M. 2006. «Tipologías de viveros de empresas: tradicionales y especializados». Investigaciones Europeas de Dirección y Economía de la Empresa. 12( 1): 133-152.

Más-Verdú, F., Wensley, A.; M artín, A. and García Álvarez-Coque, J.M . 2011. «How much does KIBS contribute to the generation and diffusion of innovation?» Service Business. 5(3): $195-$ 
212.

M cAdam, M., and M arlow, S. 2011. Sense and sensibility: The role of business incubator client advisors in assisting high-technology entrepreneurs to make sense of investment readiness status. Entrepreneurship \& Regional Development. 23(7-8): 449-468.

Mian, S. A. (1997). «Assessing and managing the university technology business incubator: an integrative framework». Journal of Business Venturing. 12(4): 251-285.

Middleton, M.; Schaeffer, P.V. and Jackson, R.W. 2012. «An Analysis of Administrative "Best Practices " in the Administration of Business Incubators». Regional Research Institute. Working Paper Series. West Virginia University.

Nicholls, J., Lawlor, E., Neitzert, E., and Goodspeed, T. 2009. «A guide to social return on investment». London: Office of the Third Sector. The Cabinet Office.

Ortega Cachón, I. 2012. «Medición del impacto socioeconómico y evaluación de las políticas públicas de apoyo a emprendedores e impulso de la creación de empresas». Doctoral Thesis. Universidad Rey Juan Carlos I. Madrid.

Pergelova, A., and Angulo-Ruiz, F. 2014. «The impact of government financial support on the performance of new firms: the role of competitive advantage as an intermediate outcome». Entrepreneurship \& Regional Development. 26(9-10): 663-705.

Pigou, A. C. (2013). The economics of welfare. Palgrave M acmillan. London.

Steyaert, C., and Katz, J. (2004). "Reclaiming the space of entrepreneurship in society: geographical, discursive and social dimensions». Entrepreneurship \& Regional Development. 16(3): 179-196.

Setyawan, A.B. and Suyudi, I. 2014. «Business incubator, one concrete effort to keep, maintain, and increase the role of small and medium enterprises (SMEs)». In Recent Trends in Social and Behaviour Sciences: Proceedings of the International Congress on Interdisciplinary Behaviour and Social Sciences 2013. CRC Press.

Stiglitz, J. E. 1992. «Economics of the Public Sector». Norton. New York.

Stoforos, C., Kavcic, S., Erjavec, E., and M ergos, G. (2000). «Agricultural policy analysis model for Slovenian agriculture». Selective readings on economies in transition. Cahier Options Mediterraneennes. 44: 91-102.

Unión Europea. 2003. «Guía del análisis coste-beneficio de los proyectos de inversión». Internet 


\section{Document.}

http://ec.europa.eu/regional_policy/sources/docgener/guides/cost/guide02_es.pdf.

Vanderstraeten, J., and Matthyssens, P. 2010. «Measuring the performance of business incubators: A critical analysis of effectiveness approaches and performance measurement systems». In ICSB World Conference Proceedings . International Council for Small Business (ICSB).

Voisey, P., Gornall, L., Jones, P., and Thomas, B. (2006). «The measurement of success in a business incubation project». Journal of Small Business and Enterprise Development. 13(3): 454-468. 


\section{APPENDIX}

Table 6. Profitability and efficiency of Valencian-Community-based business incubators ${ }^{5}$.

\begin{tabular}{|c|c|c|c|c|c|c|c|c|c|c|c|c|c|}
\hline \multirow[b]{2}{*}{ Entity } & \multirow[b]{2}{*}{ Orient. } & \multirow[b]{2}{*}{ Incubator } & \multirow{2}{*}{$\begin{array}{c}\text { Contribution } \\
\text { per firm }(€)\end{array}$} & \multicolumn{2}{|c|}{ Firms } & \multicolumn{2}{|c|}{ Jobs } & \multirow{2}{*}{$\begin{array}{l}\text { Staff } \\
\text { (No.) }\end{array}$} & \multirow{2}{*}{$\begin{array}{l}\text { Area } \\
\left(\mathrm{m}^{2}\right)\end{array}$} & \multirow{2}{*}{$\begin{array}{l}\text { Equip. } \\
\text { (No.) }\end{array}$} & \multirow{2}{*}{$\begin{array}{l}\text { Servic. } \\
\text { (no) }\end{array}$} & \multirow[b]{2}{*}{ OR (\%) } & \multirow{2}{*}{$\begin{array}{l}\text { (average) } \\
\text { Assess. }\end{array}$} \\
\hline & & & & 2014 & Start & 2014 & Start & & & & & & \\
\hline C. Commerce & Services & Valencia 1 & 11,754 & 16 & 28 & 75 & 111 & 2 & 620 & 7 & 10 & 94.1 & 3.4 \\
\hline European BIC & Techno. & Castellón 1 & 9,257 & 20 & 230 & 70 & 1,200 & 9 & 2,100 & 12 & 16 & 80.0 & 3.6 \\
\hline Uni-foundat. & Techno. & Valencia 2 & 13,941 & 14 & 62 & 65 & 130 & 7 & 600 & 8 & 13 & 100.0 & 4.0 \\
\hline Town Council & Industrial & Alicante 1 & 10,895 & 12 & 12 & 50 & 50 & 1 & 25,000 & 5 & 3 & 100.0 & 2.0 \\
\hline Uni-foundat. & Techno. & Alicante 2 & 5,537 & 20 & 55 & 48 & 90 & 8 & 7,832 & 14 & 18 & 57.1 & 3.9 \\
\hline Town Council & Industrial & Alicante 3 & 6,374 & 19 & 34 & 40 & 70 & 1 & 6,000 & & & 100.0 & 2.4 \\
\hline European BIC & Techno. & Alicante 4 & 5,211 & 10 & 312 & 36 & 1,150 & 3 & 750 & 13 & 18 & 58.8 & 3.6 \\
\hline C. Commerce & Services & Alicante 5 & 10,311 & 8 & 16 & 36 & 60 & 3 & 400 & 7 & 1 & 61.5 & 2.9 \\
\hline Uni-foundat. & Techno. & Alicante 6 & 9,881 & 8 & 10 & 35 & 35 & 3 & 250 & 11 & 9 & 100.0 & \\
\hline European BIC & Techno. & Alicante 7 & 4,760 & 15 & 200 & 33 & 450 & 9 & 2,394 & 11 & 16 & 51.7 & 3.6 \\
\hline Town Council & Services & Alicante 8 & 4,466 & 13 & 30 & 32 & 71 & 1 & 525 & 10 & 6 & 100.0 & 3.3 \\
\hline C. Commerce & Services & Valencia 3 & 6,503 & 11 & 19 & 28 & 44 & 2 & 462 & 7 & 10 & 73.3 & 3.2 \\
\hline European BIC & Techno. & Valencia 4 & 4,308 & 23 & 305 & 66 & 2,765 & 12 & 4,375 & 11 & 15 & 74.1 & \\
\hline C. Commerce & Services & Alicante 9 & 3,805 & 15 & 22 & 22 & 33 & 1 & 780 & 9 & 8 & 100 & 3.0 \\
\hline C. Commerce & Services & Alicante 10 & 4,777 & 15 & 15 & 22 & 22 & 1 & 582 & 9 & 8 & 100 & \\
\hline \multicolumn{3}{|l|}{ Average } & 5,024 & 9.3 & 37.0 & 21.4 & 106.5 & 2.2 & $2,200.8$ & 7.4 & 8.9 & 64.5 & 3.3 \\
\hline C. Commerce & Services & \begin{tabular}{|l|} 
Valencia 5 \\
\end{tabular} & 6,371 & 9 & 20 & 20 & 38 & . & 315 & 7 & 10 & 90.0 & 3.6 \\
\hline C. Commerce & Services & Valencia 6 & 3,046 & 14 & 24 & 19 & 29 & 1 & 591 & 7 & 10 & 73.7 & 3.3 \\
\hline Uni-foundat. & Techno. & Alicante 11 & 6,134 & 7 & 22 & 19 & 60 & 2 & 111 & 12 & 13 & 77.7 & \\
\hline C. Commerce & Services & Castellón 2 & 1,952 & 14 & 39 & 18 & 50 & 4 & 1,000 & 6 & 4 & 38.9 & \\
\hline C. Commerce & Industrial & Alicante 12 & 6,419 & 9 & 9 & 18 & 18 & & 18,000 & 2 & 8 & 40.9 & \\
\hline C. Commerce & Services & Alicante 13 & 2,875 & 11 & 21 & 16 & 30 & 1 & 540 & 9 & 8 & 50.0 & \\
\hline C. Commerce & Industrial & Alicante 14 & 6,347 & 7 & 13 & 14 & 26 & & 5,086 & 2 & 8 & 38.9 & \\
\hline C. Commerce & Services & Alicante 15 & 907 & 9 & 9 & 12 & 12 & 1 & 2,821 & 9 & 8 & 43.5 & \\
\hline Town Council & Techno. & Castellón 3 & $-11,744$ & 5 & 18 & 11 & 26 & 2 & 1,529 & 11 & 13 & 40.0 & 4.3 \\
\hline C. Commerce & Services & Valencia 7 & 2,205 & 8 & 24 & 10 & 31 & 1 & 282 & 7 & 10 & 90.0 & 2.9 \\
\hline Town Council & Services & Valencia 8 & 5,538 & 5 & 6 & 10 & 12 & 1 & 150 & 5 & 7 & 83.3 & 2.8 \\
\hline C. Commerce & Services & Valencia 9 & 2,480 & 7 & 22 & 7 & 25 & 1 & 263 & 7 & 10 & 77.8 & 2.9 \\
\hline C. Commerce & Services & Alicante 16 & 148 & 7 & 7 & 7 & 7 & 1 & 900 & 9 & 8 & 33.3 & 3.0 \\
\hline Town Council & Services & Valencia 10 & 4,375 & 3 & 5 & 7 & 12 & 1 & 224 & 6 & 1 & 37.5 & 4.0 \\
\hline C. Commerce & Services & Valencia 11 & 4,450 & 3 & 14 & 6 & 36 & & 154 & 7 & 10 & 83.3 & 2.3 \\
\hline Town Council & Services & Alicante 17 & 617 & 10 & 15 & 5 & 8 & 3 & 1,205 & 2 & 2 & 76.9 & 2.6 \\
\hline C. Commerce & Services & Valencia 12 & 2,371 & 5 & 17 & 5 & 25 & . & 160 & 7 & 10 & 71.4 & 3.0 \\
\hline C. Commerce & Services & Alicante 18 & $-4,919$ & 4 & 12 & 5 & 15 & 2 & 800 & 8 & 11 & 22.2 & 3.0 \\
\hline
\end{tabular}

${ }^{5}$ To avoid local names of business incubators, without interest for international readers, we will name the different incubators as Alicante 1, 2, etc., Valencia 1, 2, etc. and Castellón 1, 2, etc. 
Table 6. Profitability and efficiency of Valencian-Community-based business incubators ${ }^{5}$.

\begin{tabular}{|c|c|c|c|c|c|c|c|c|c|c|c|c|c|}
\hline \multirow[b]{2}{*}{ Entity } & \multirow[b]{2}{*}{ Orient. } & \multirow[b]{2}{*}{ Incubator } & \multirow{2}{*}{$\begin{array}{l}\text { Contribution } \\
\text { per firm }(€)\end{array}$} & \multicolumn{2}{|c|}{ Firms } & \multicolumn{2}{|c|}{ Jobs } & \multirow{2}{*}{$\begin{array}{l}\text { Staff } \\
\text { (No.) }\end{array}$} & \multirow{2}{*}{$\begin{array}{r}\text { Area } \\
\left(\mathrm{m}^{2}\right)\end{array}$} & \multirow{2}{*}{$\begin{array}{l}\text { Equip. } \\
\text { (No.) }\end{array}$} & \multirow{2}{*}{$\begin{array}{c}\text { Servic. } \\
\text { (no) }\end{array}$} & \multirow[b]{2}{*}{ OR (\%) } & \multirow{2}{*}{$\begin{array}{c}\text { (average) } \\
\text { Assess. }\end{array}$} \\
\hline & & & & 2014 & Start & 2014 & Start & & & & & & \\
\hline Town Council & Services & Valencia 13 & $-7,378$ & 3 & 4 & 4 & 4 & 1 & 120 & 6 & 5 & 33.3 & 3.3 \\
\hline Town Council & Services & Valencia 14 & 1,704 & 2 & 2 & 3 & 3 & 1 & 300 & 8 & 10 & 50.0 & \\
\hline Town Council & Services & Valencia 15 & $-6,581$ & 3 & 11 & 2 & 6 & 3 & 300 & 6 & 8 & 75.0 & \\
\hline Town Council & Services & Valencia 16 & $-4,756$ & 3 & 6 & 2 & 2 & 2 & 200 & 4 & 7 & 60.0 & 2.9 \\
\hline Town Council & Services & \begin{tabular}{|l|} 
Alicante 19 \\
\end{tabular} & $-6,157$ & 1 & 15 & 1 & 17 & 2 & 200 & 6 & 3 & 20.0 & \\
\hline Town Council & Services & \begin{tabular}{|l|} 
Alicante 20 \\
\end{tabular} & $-7,814$ & & 25 & & 39 & 1 & 86 & 7 & 18 & - & \\
\hline
\end{tabular}

Source: Elaborated by the authors 